\title{
Neonatal outcomes of preterm infants born to preeclamptic mothers
}

\author{
Preeklamptik anne bebeklerinin neonatal dönem prognozları
}

Burcu BURSAL DURAMAZ, Leyla BİLGIN, Özgül SALIHOGLU, Kerem ERTAŞ, Sami HATIPOĞLU

\begin{abstract}
Objectives: Preeclampsia is a major cause of maternal, fetal and neonatal morbidity and mortality. The aim of this study was to determine neonatal outcomes of premature infants born to preeclamptic mothers.

Patients and Methods: Preterm infants $\leq 36$ gestational age who were born to preeclamptic mothers and normotensive mothers were included in this study. Infant's data including demographic characteristics, neonatal morbidities and mortalities were evaluated retrospectively.

Results: Hundred and forty infants born to preeclamptic mothers (study group) and 144 infants born to normotensive mothers (control group) were included. No statistical difference was found between mean gestational age, birth weight, Apgar scores at 1 and 5 minutes, and in terms of sex ratio. Cesarean delivery, small gestational age and neutropenia rates were found significantly higher in the study group. Other neonatal morbidities such as necrotising enterocolitis and sepsis were also found higher in the study group but it was not statistically significant. Hospitalization and mortality rates were similar in both groups.

Conclusions: Preeclampsia was associated with increased cesarean delivery, small gestational age and neutropenia. There were no significant differences between other morbidities and mortality of two groups. We think that prematurity is the main risk factor of morbidity and mortality regardless of concomitant.
\end{abstract}

Keywords: Preeclampsia, Premature infant, Neonatal mortality, Morbidity

Burcu Bursal Duramaz (四), Sami Hatipoğlu

Department of Pediatrics, Bakirkoy Dr. Sadi Konuk Education and Research Hospital, Istanbul, Turkey

e-mail: burcubursal@hotmail.com

Leyla Bilgin

Department of Neonatology, Umraniye Education and Research Hospital, Istanbul, Turkey

Özgül Salihoğlu

Department of Neonatology, Bakirkoy Dr Sadi Konuk Education and Research Hospital, Istanbul, Turkey

Kerem Ertaş

Department of Pediatrics, School of Medicine, Firat University, Elazig, Turkey

Submitted / Gönderilme: 04.09.2016

Accepted/Kabul: 19.12 .2016
ÖZ

Amaç: Preeklampsi, maternal, fetal ve neonatal morbiditenin ve mortalitenin en önemli nedenlerinden birisidir. Çalışmamızda preeklamptik anne bebeklerinin neonatal dönem prognozlarını araştırmak amaçlandi.

Hastalar ve Yöntemler: Çalışmaya preeklamptik ve normotansif annelerden doğan 36. gestasyonel haftadan küçük bebekler dahil edildi. Bebeklerin demografik özellikleri, neonatal morbiditeleri ve mortaliteleri retrospektif olarak belirlendi.

Bulgular: Çalışmaya preeklamptik annelerden doğan 140 bebek (çalışma grubu) ile normotansif annelerden doğan 144 bebek (kontrol grubu) dahil edildi. Çalışma grubu ve kontrol grubu arasında gestasyonel hafta, doğum tartıs1, 1. ve 5. dakika Apgar skorları ve cinsiyet açısından istatistiksel olarak anlamlı farklılık saptanmadi. Sezeryan doğum, düşük gestasyonel hafta ve nötropeni oranları çalışma grubunda istatistiksel olarak yüksek saptandı. Nekrotizan enterokolit ve sepsis gibi neonatal morbiditeler de çalışma grubunda sayıca yüksek olmasına rağmen istatiksel anlamlılık saptanmadi. Hastaneye yatış ve mortalite oranları her iki grupta benzerdi.

Sonuçlar: Çalışmamızda preeklampsi, sezeryan doğum, düşük gestasyonel hafta ve nötropeni ile ilişkili saptandi. Diğer morbiditeler ve mortalite açısından iki grup arasında anlamlı fark saptanmadi. Bu yüzden preeklamptik anne bebeklerinin karşılaştığ problemlerin çoğunun preeklampsiden ziyade prematürite ve bununla ilişkili komplikasyonlar sonucu olduğunu düşünmekteyiz.

Anahtar kelimeler: Preeklampsi, Prematur infant, Neonatal mortalite, Morbidite

\section{Introduction}

Hypertensive diseases are one of the most frequent medical complications in pregnancy, and the main reasons of maternal, fetal, and neonatal morbidity and mortality [1]. Preeclampsia is a systemic disease of pregnancy with hypertension, proteinuria, and edema, which affects the fetus because of utero-placental deficiency, that leads to growth retardation [2]. Preeclampsia is reported in approximately $2-8 \%$ of pregnancies. The incidence may vary according to race, region, and country [3]. The etiology of preeclampsia is still uncertain. Diabetes mellitus, kidney disease, obesity, 
nulliparity, and chronic hypertension are associated with increased preeclampsia risk. Birth of placenta is the major treatment of preeclampsia. There are different articles about neonatal outcomes of infants born to preeclamptic mothers [4]. On the other hand, controversial outcomes are available in the current literature.

The aim of our study was to evaluate the neonatal outcomes of preterm infants born to preeclamptic mothers admitted to our clinic.

\section{Materials and Methods}

After the local ethics committee approval, we retrospectively evaluated the neonatal outcomes of 140 infants born between 24 and 36 weeks of gestational age from preeclamptic mothers during the period from January 2009 to December 2013 in the neonatal intensive care unit (NICU). The study group was compared with 144 infants born to normotensive mothers of the same gestational age. Infants with chromosomal or major congenital anomalies were not included. The following variables were recorded: maternal age, gravidity, mode of delivery, Apgar score (1st and 5th minute), gestational age, birth weight, sex, presence of small-for-gestational-age (SGA), respiratory distress syndrome (RDS), intraventricular hemorrhage (IVH), neonatal sepsis, necrotizing enterocolitis (NEC), bronchopulmonary dysplasia (BPD), retinopathy of prematurity (ROP), as well as laboratory values (leukocyte count, platelet count, hemoglobin), days in the NICU, ventilation requirement, and mortality rate.

The criteria of preeclampsia are new-onset hypertension (defined as systolic blood pressure $\geq 140 \mathrm{~mm} \mathrm{Hg}$ or diastolic blood pressure $\geq 90 \mathrm{~mm} \mathrm{Hg}$ ) and proteinuria (300 $\mathrm{mg}$ or greater in a 24-h urine specimen) after 20 weeks of gestation [5]. Gestational age was interpreted with obstetric history and early obstetric ultrasound, and verified using the modified Ballard examination with newborn infants' clinical examination. SGA was described as being below the $10 \%$ percentile of the recommended sex-specific birth weight for gestational age reference curves. RDS was described as clinical findings (tachypnea, retractions or nasal flaring, grunting respiration, and possible central cyanosis) and radiologic findings (reticular granular pattern or air bronchograms) [6]. IVH was identified using the Papile classification system [7]. For the identification of neonatal sepsis, we interpreted the clinical signs of systemic inflammation (temperature instability, apnea, respiratory distress, seizures, tachypnea, bradycardia, abdominal distension and vomiting), routine laboratory tests such as leukocytosis or leukopenia and C-reactive protein (CRP) results $>1 \mathrm{mg} / \mathrm{dL}$, and if possible we isolated the causal microorganisms from blood cells or cerebrospinal fluid culture [8]. NEC was categorized in conformity with the modified Bell's criteria [9]. The criteria for diagnosis of BPD were oxygen dependency at 28 days of life or longer along with a concordant chest radiograph. Moderate to severe BPD in preterm neonates with less than 32 weeks of gestational age was described as dependence on supplemental oxygen at 36 weeks of postconceptional age [10]. ROP was categorized in accordance with the International Classification of ROP [11]. Thrombocytopenia was described as a platelet count of $<150000 / \mathrm{mm} 3$. Polycythemia was identified as a central venous hematocrit (Hct) level greater than $65 \%$, leukopenia was described as a leukocyte count of $<5000 / \mathrm{mm} 3$, and leukocytosis was identified as a leucocyte count of $>21000$ $/ \mathrm{mm} 3$ two days after the day of birth.

Data was analyzed using the Number Cruncher Statistical System (NCSS) 2007 (Utah, USA) statistical software. Descriptive statistics are given as mean $\pm \mathrm{SD}$, median, and interquartile range. The independent $t$-test was used in the comparison of variables with normal distribution, and the Mann-Whitney $U$ test was used in the comparison of variables with non-normal distribution. For the comparison of qualitative data, Pearson's Chi-square, Fisher's exact, and Fisher-Freeman-Halton tests were used. A P value $<0.05$ was considered statistically significant.

\section{Results}

A total of 284 infants, 140 born to preeclamptic mothers (study group) and 144 born to normotensive mothers (control group) were included in the study. The mean gestational age of the study and control groups were $31.5 \pm 3.2$ and $30.9 \pm 3.1$ weeks, respectively $(\mathrm{p}>0.05)$. The mean birth weights of the study and control groups were similar $(1592 \pm 493$ and $1596 \pm 491 \mathrm{~g}$, respectively). There were also no statistically significant differences between the groups with regards to sex, mean Apgar scores at 1 and 5 minutes, and rates of antenatal corticosteroid use $(\mathrm{p}>0.05)$. The cesarean birth rate in infants of the study and control groups was $98.6 \%$ and $73.6 \%$, respectively, and the difference was statistically significant $(\mathrm{p}<0.01)$. The rate of SGA in infants in the study group was also significantly higher compared with the control group $(p<0.01)$. Demographic data of the patients are summarized in Table I. 
Table I. Demographic features of study and control groups

\begin{tabular}{|c|c|c|c|}
\hline Demographic feature & Study group $(n=140)$ & Control group $(n=144)$ & $P$ value \\
\hline Sex (male/female) & $73 / 67$ & $75 / 69$ & $>0.05$ \\
\hline Gestational age (week) & $31.5 \pm 3.2$ & $30.9 \pm 3.1$ & $>0.05$ \\
\hline Cesarean delivery, n (\%) & $138(98.6)$ & $106(73.6)$ & $<0.01$ \\
\hline Small for gestational age (SGA), $n(\%)$ & $17(12.1)$ & $3(2.1)$ & $<0.01$ \\
\hline Birth Weight (g) & $1592 \pm 492$ & $1596 \pm 491$ & $>0.05$ \\
\hline Apgar score at $1^{\text {st }}$ minute & $6.26 \pm 2.10$ & $6.21 \pm 1.85$ & $>0.05$ \\
\hline Apgar score at $5^{\text {th }}$ minute & $8.67 \pm 1.08$ & $8.63 \pm 1.10$ & $>0.05$ \\
\hline Antenatal corticosteroid, n (\%) & $37(63.8)$ & $45(6.2)$ & $>0.05$ \\
\hline
\end{tabular}

Neonatal thrombocytopenia was diagnosed in 60 $(42.9 \%)$ infants in the study group and 58 (40.3\%) in the control group; there was no significant difference between the groups. Neutropenia was diagnosed in 33 $(23.6 \%)$ infants of study group and $16(11.1 \%)$ in the control group, the difference between the two groups was statistically significant $(p<0.05)$. The mean duration of neutropenia was 11 days (range, 2-25 days) and 6.5 days (range, 1-36.5 days) in the study and the control group, respectively. Although the difference was not statistically significant, the duration of neutropenia was longer in the study group. Neonatal sepsis was diagnosed in 22 (15.7\%) infants in the study group and in $16(11.1 \%)$ in the control group; this difference was not significant. There were no significant differences in terms of neonatal polycythemia, RDS, ROP, IVH, NEC, duration of mechanical ventilation, duration of hospital stay, and BPD between the study and control groups. Mortality rates were also similar between the study and control groups $(7.9 \%$ and $11 . .8 \%$, respectively). Neonatal outcomes among the study and control groups are summarized in Table II. There were no significant differences between the two groups in terms of abnormal neurologic examination findings and incidence of periventricular leucomalacia at discharge.

Table II. Perinatal outcomes and laboratory findings of the study and control groups

\begin{tabular}{|c|c|c|c|}
\hline Perinatal Outcomes & Study group $(n=140)$ & Control group $(n=144)$ & $P$ value \\
\hline Duration of mechanical ventilation (days) & $8.9 \pm 30.3$ & $7.4 \pm 14.0$ & $>0.05$ \\
\hline Primary hospital stay (days) & $30.7 \pm 34.5$ & $32.5 \pm 28.7$ & $>0.05$ \\
\hline Thrombocytopenia, n (\%) & $60(42.9)$ & $58(40.3)$ & $>0.05$ \\
\hline Neutropenia, n (\%) & $33(23.6)$ & $16(11.1)$ & $<0.05$ \\
\hline Polycythemia, n (\%) & $4(2.9)$ & $4(2.8)$ & $>0.05$ \\
\hline RDS, n (\%) & $69(49.3)$ & $81(56.3)$ & $>0.05$ \\
\hline IVH, n (\%) & $27(19.3)$ & $24(16.7)$ & $>0.05$ \\
\hline NEC, n (\%) & $22(15.7)$ & $16(11.1)$ & $>0.05$ \\
\hline Sepsis, n (\%) & $22(15.7)$ & $16(11.1)$ & $>0.05$ \\
\hline BPD, n (\%) & $13(9.3)$ & $16(11.1)$ & $>0.05$ \\
\hline ROP, n (\%) & $8(5.7)$ & $8(5.5)$ & $>0.05$ \\
\hline Neonatal mortality, n (\%) & $11(7.9)$ & $17(11.8)$ & $>0.05$ \\
\hline
\end{tabular}

RDS: respiratory distress syndrome, IVH: intraventricular hemorrhage, NEC: necrotizing enterocolitis, BDP: bronchopulmonary dysplasia, ROP: retinopathy of prematurity 
We further classified groups into two subgroups according to the gestational weeks, group 1: 24-32 weeks, and group 2: 32-36 weeks. Group 1 consisted of 126 infants (58 from the study group, 68 from the control group), and group 2 comprised 158 infants (82 from the study group, 76 from the control group). Among patients in group 1, the duration of mechanical ventilation was significantly longer in infants from the study group when compared with the control group $(15.1 \pm 21.9$ vs $11.9 \pm 18$ days $)(p<0.01)$. No significant difference was determined between the study and control groups in terms of neonatal morbidity, mortality, and laboratory findings when compared separately regarding the gestational ages in groups 1 and $2(\mathrm{p}>0.05)$.

\section{Discussion}

Preeclampsia was related to maternal and perinatal incidence of mortality, morbidity, and prematurity [12]. The time of initiation of preeclampsia in pregnancy and severity of the disease, performed obstetric care approaches, and level of nursing in NICUs affect the results in infants. In the present study, we aimed to investigate neonatal outcomes of infants born to preeclamptic mothers. In our study, neonatal outcomes of infants of preeclamptic mothers were generally similar to the outcomes of infants of normotensive mothers. However, cesarean delivery rates and SGA birth rates were significantly higher in the study group than in the control group.

Different results have been reported linked to the results of infants born to preeclamptic mothers in the literature. Saadat et al. [13] showed that cesarean delivery was more frequent in preeclamptic mothers $(30 \%)$ as compared with normotensive mothers (13\%). Çetinkaya et al. also found that the rate of cesarean delivery was higher in preeclamptic mothers than in normotensive mothers (78\% vs. $60 \%)$ but the difference was not statistically significant $(p>0.05)$ [14]. Similarly, the frequency of cesarean delivery was higher in our study group, but the difference was statistically significant $(\mathrm{p}<0.01)$.

Bülbül et al. found that the rate of SGA infants in their preeclampsia group was higher but the difference was not statistically significant (14-17\%, p>0.05) [3]. Similarly, Anand et al. showed that the incidence of SGA infants was four times more common in the hypertensive group (44.5\% vs. $11 \%$ ) [15]. We also showed that the rate of SGA infants was statistically significantly higher in the study group compared with the control group $(\mathrm{p}<0.01)$.
There were different results linked to RDS when infants born to preeclamptic mothers and normotensive mothers were checked. Interestingly, Langenveld et al. showed that the risk of RDS was reduced in infants of preeclamptic mothers who were delivered between 34 and 37 weeks of gestation compared with controls born to normotensive mothers [16]. In contrast, Chang et al. showed an increased risk of RDS in early preeclamptic premature infants with $<32$ weeks of gestational age [17]. Cheng et al. reported no differences between preeclamptic and control infants in terms of respiratory outcomes [4]. In the current study, we found no differences between preeclamptic and control infants in terms of RDS. Differences in RDS description and the retrospective analysis of RDS may explain for these variations. We also stated that time of mechanical ventilation and BPD showed no variation between the two groups. However, when we encountered the gestational week subgroups (group 1: 24-32 weeks, group 2: 32-36 weeks), the duration of mechanical ventilation was significantly longer in the study group compared with the control group among infants with 24-32 weeks of gestational age. Based on these results, we can argue that preeclampsia widens the duration of mechanical ventilation in infants with gestational age of less than 32 weeks. We could not find any similar studies in the literature; therefore, we believe that larger studies are warranted to investigate respiratory outcomes of infants born to preeclamptic mothers.

Intraventricular hemorrhage is a critical complication seen in premature infants. IVH is one of the major significant reason of neonatal morbidity that may cause brain damage resulting in cognitive and motor disabilities, cerebral palsy, and mental retardation [18]. Cheng et al. reported an IVH rate of $50 \%$ for infants born to preeclamptic mothers and $26 \%$ for controls [4]. In contrast, Çetinkaya et al. determined that the difference in IVH incidence was not statistically significant when infants born to preeclamptic mothers were compared with controls [14]. We found similar results in our study. We do not know the long-term neurologic results of these infants because this was a retrospective study, which may be the topic of a new study.

Neutropenia has been showed in infants of preeclamptic mothers with an incidence of 50\% [19]. Neutropenia may be related with an increased risk of nosocomial infections. Gray and Rodwell [20] concluded that prolonged neutropenia might be responsible for the increased incidence of nosocomial infections in infants born to preeclamptic mothers. Conflictingly, Paul et al. [21] showed that 
very-low-birth-weight infants born to preeclamptic mothers were not at increased risk of culture-proven sepsis despite a reduction in an absolute number of neutrophils. In our study, the prevalence of neutropenia among infants of preeclamptic mothers was $23.6 \%$, which was statistically significantly more common compared with infants of normotensive mothers $(p<0.05)$. Neonatal sepsis was also found more common in infants born to preeclamptic mothers. This result shows that neutropenia can be demonstrated as a cause of sepsis. There are many predisposing factors for sepsis. The risk of sepsis in infants born to preeclamptic mothers is still controversial. Maternal preeclampsia was also described as a cause of neonatal thrombocytopenia [22]. Thrombocytopenia is generally identified at birth or within the first 2-3 days after delivery, with resolution in 10 days in most cases [23]. Thrombocytopenia was also higher in the study group, but not statistically significantly $(42.9 \%$ vs. $40.3 \%$ ). Different incidences of thrombocytopenia have been reported, up to as much as $36 \%$ by Bhat et al. [24].

Necrotizing colitis is a serious reason of mortality and morbidity in preterm infants. Although the pathophysiology of NEC is multifactorial, prematurity, low birth weight, enteral feeding, and neonatal infection are obvious predisposing factors for the occurrence of NEC [25]. There are a variety of outcomes in the literature about preeclampsia and its relationship with NEC. Bashiri et al. reported an association between maternal hypertensive disorders and NEC in very-low-birth- weight infants [25]. In contrast, Hiett et al. stated that NEC was not increased in infants born to preeclamptic mothers [26]. In our study, in agreement with the latter, the incidence of NEC was higher in infants born to preeclamptic mothers, but the difference between the two groups was not statistically significant.

Preterm infants are at an elevated risk for ROP. Zayed et al. found no associations between gestational hypertension and ROP severity score [27]. Filho et al. reported that preeclampsia decreased the risk of retinopathy of prematurity occurrence in very-low-birth-weight infants [28]. Dan Yu et al. also showed that preeclampsia was associated with a significantly lowered risk of ROP [29]. On the other hand, Çetinkaya et al. reported that there were no significant differences in terms of ROP between their study and control groups $(\mathrm{P}>0.05)$ [14]. In our study, we found similar results regarding the incidence of ROP.

There are contraversial results about the mortality ratio of infants born to preeclamptic mothers. Çetinkaya et al. reported that there were no significant differences in mortality rates between infants born to preeclamptic mothers compared with control infants [14]. Güran et al. showed that mortality $(18.9 \%$ vs. $26.9 \%, p=0.23)$ was lower in infants of preeclamptic mothers although there was no statistically significant difference [3]. In our study, we found that the mortality rate was lower in the preeclamptic group compared with controls, but the difference was not statistically significant ( $7.8 \%$ vs. $11.8 \%)$.

There are limitations to our study. First, our study was retrospective and based on the results of a single center and included a small number of patients. There is a need for further prospective studies on this issue with a greater number of patients. Secondly, the severity of preeclampsia was not considered as a variable in our study. Finally, we were unable to follow long term results of the patients so after discharge status of patients are unknown. Therefore, we could not determine the long-term neurocognitive and respiratory outcomes of our patients.

\section{Conclusion}

In the present study, preeclampsia was associated with increased rates of SGA, cesarean births, neutropenia, and extended duration of mechanical ventilation among infants born below 32 weeks of gestational age. Neonatal morbidity and mortality rates were similar between infants born to preeclamptic or normotensive mothers. These findings indicate that neonatal outcomes of preeclampsia were dependent on prematurity and were related to premature deliveries of preeclamptic women, not only preeclampsia itself.

\section{References}

1. Tavassoli F, Ghasemi M, Ghomian N, Ghorbani A, Tavassoli $\mathrm{S}$. Maternal and perinatal outcome in nulliparous women complicated with pregnancy hypertension. J Pak Med Assoc 2010; 60:707-10.

2. Sibai BM. Diagnosis, prevention and management of preeclampsia. Obstet Gynecol 2005; 105:402-10. doi:10.1097/01.AOG.0000152351.13671.99

3. Güran Ö, Uslu S, Bülbül A, et al. Early neonatal outcomes of very low birth weight infants of preeclamptic mothers. JAREM 2012; 2:64-7. doi: 10.5152/jarem.2012.16

4. Ozkan H, Cetinkaya M, Koksal N. Increased incidence of bronchopulmonary dysplasia in preterm infants exposed to preeclampsia. J Matern-Fetal Neonat Med 2012; 25:2681-5. doi: $10.3109 / 14767058.2012 .708371$ 
5. Noris M, Perico N, Remuzzi G. Mechanisms of disease: pre-eclampsia. Nat Clin Pract Nephrol 2005; 1:98-114. doi: 10.1038/ncpneph0035

6. Lee H, Shim SY, Park E, Cho SJ. The clinical features and prognosis of nephrocalcinosis in preterm neonates: A single center study in Korea. Neonatal Med 2016; 23:131-6. doi: 10.5385/nm.2016.23.3.131

7. Strahle J, Garton HJ, Maher CO, Muraszko KM, Keep RF, $\mathrm{Xi} \mathrm{G}$. Mechanisms of hydrocephalus after neonatal and adult intraventricular hemorrhage. Trans Stroke Res 2012; 3:2538. doi:10.1007/s12975-012-0182-9

8. Nwadioha SI, Nwokedi EOP, Kashibu E, Odimayo MS, Okwori EE. A review of bacterial isolates in blood cultures of children with suspected septicemia in a Nigerian Tertiary Hospital. Afric J Microbiol Res 2010; 4:222-5.

9. Perrone S, Tataranno ML, Negro S, et al. May oxidative stress biomarkers in cord blood predict the occurrence of necrotizing enterocolitis in preterm infants? J Matern-Fetal Neonat Med 2012; 25 (sup1):128-31. doi: 10.3109/14767058.2012.663197

10. An HS, Bae EJ, Kim GB, et al. Pulmonary hypertension in preterm infants with bronchopulmonary dysplasia. Korean Circul J 2010; 40:131-6. doi: 10.4070/kcj.2010.40.3.131

11. Araz-Ersan B, Kir N, Akarcay K, et al. Epidemiological analysis of retinopathy of prematurity in a referral centre in Turkey. Br J Ophthalmol 2013; 97:15-7. doi:10.1136/ bjophthalmol-2011-301411

12. Withagen MI, Visser W, Wallenburg HC. Neonatal outcome of temporizing treatment in early-onset preeclampsia. Eur J Obstet Gynecol Reprod Biol 2001; 94:211-5. doi: 10.1016/ S0301-2115(00)00332-8

13. Kampruan R, Sukonpan K, Wasinghon P. Pregnancy outcomes amongst normotensive and severe preeclampsia with or without underlying chronic hypertension pregnancy. Thai J Obstet Gynaecol 2016; 24:202-8. doi: 10.14456/ tjog.2016.29

14. Çetinkaya M, Özkan H, Köksal N, Karali Z, Özgür T. Neonatal outcomes of premature infants born to preeclamptic mothers. J Matern-Fetal Neonat Med 2010; 23:425-30. doi: $10.3109 / 14767050903184173$

15. Donimath KV, Sambrani AM, Rathod PM. A study on association of thrombocytopenia with pregnancy induced hypertension. Int J Reprod Contracept Obstet Gynecol 2016; 5:808-12. doi: 10.18203/2320-1770.ijrcog20160589

16. Langenveld J, Ravelli AC, van Kaam AH, et al. Neonatal outcome of pregnancies complicated by hypertensive disorders between 34 and 37 weeks of gestation: a 7-year retrospective analysis of a national registry. Am J Obstet Gynecol 2011; 205:540. doi: 10.1016/j.ajog.2011.07.003

17. Chang EY, Menard MK, Vermillion ST, Hulsey T, Ebeling $\mathrm{M}$. The association between hyaline membrane disease and preeclampsia. Am J Obstet Gynecol 2004; 191:1414-7. doi: 10.1016/j.ajog.2004.06.097

18. Fanaroff AA, Stoll BJ, Wright LL, et al. Trends in neonatal morbidity and mortality for very low birthweight infants. Am J Obstet Gynecol 2007; 196:147. doi: 10.1016/j. ajog.2006.09.014

19. Kumar S, Haricharan KR. Neonatal thrombocytopenia associated with gestational hypertension, preeclampsia and eclampsia: a case-control study. In J Contemp Pediatr 2016; 3: 16-21. doi: 10.18203/2349-3291.ijcp20151385

20. Gray PH, Rodwell RL. Neonatal neutropenia associated with maternal hypertension poses a risk for nosocomial infection. Eur J Pediatr 1999; 158:71-3. doi:10.1007/s004310051013

21. Hansen AR, Barnés CM, Folkman J, McElrath TF. Maternal preeclampsia predicts the development of bronchopulmonary dysplasia. J Pediatr 2010; 156:532-6. doi.org/10.1016/j. jpeds.2009.10.018

22. Akcan AB, Oygucu SE, Ozel D, Oygür N. Mean platelet volumes in babies of preeclamptic mothers. Blood Coagul Fibrinolysis 2011; 22:285-7. doi: 10.1097/ MBC.0b013e3283451267

23. Koenig JM, Christensen RD. The mechanism responsible for diminished neutrophil production in neonates delivered of women with pregnancy-induced hypertension. Am J Obstet Gynecol 1991; 165:467-73. doi: 10.1016/00029378(91)90118-B

24. Bhat YR, Cherian CS. Neonatal thrombocytopenia associated with maternal pregnancy-induced hypertension. Indian $\mathrm{J}$ Pediatr 2008; 75:571-3. doi:10.1007/s12098-008-0110-x

25. Bashiri A, Zmora E, Sheiner E, Hershkovitz R, ShohamVardi I, Mazor M. Maternal hypertensive disorders are an independent risk factor for the development of necrotizing enterocolitis in very low birth weight infants. Fetal Diagn Ther 2003; 18:404-7. doi: 10.1159/000073132

26. Serenius F, Ewald U, Farooqi A, Holmgren PA, Håkansson $\mathrm{S}$, Sedin G. Short term outcome after active perinatal management at 23-25 weeks of gestation. A study from two Swedish tertiary care centres. Part 1: maternal and obstetric factors. Acta Paediatr 2004; 93:945-53. doi: 10.1111/j.16512227.2004.tb02694.x

27. Zayed MA, Uppal A, Hartnett ME. New-onset maternal gestational hypertension and risk of retinopathy of prematurity. Invest Ophthalmol Vis Sci 2010; 51:4983-8. doi:10.1167/iovs. 10-5283

28. Fortes Filho JB, Costa MC, Eckert GU, Santos PG, Silveira RC, Procianoy RS. Maternal preeclampsia protects preterm infants against severe retinopathy of prematurity. T J Pediatr 2011; 158:372-6. doi: 10.1016/j.jpeds.2010.08.051

29. Yu XD, Branch DW, Karumanchi SA, Zhang J. Preeclampsia and retinopathy of prematurity in preterm births. Pediatrics 2012; 130:101-7. doi: 10.1542/peds.2011-3881 